\title{
[Review Paper] \\ Progress in the Development of Highly Efficient Photocatalytic Systems for Hydrogen Production from Water under Sunlight
}

\author{
Masao KATAYAMA $^{\dagger 1)}$ and Kazunari DomeN ${ }^{\dagger 1) *, \dagger 2)}$ \\ ${ }^{\dagger 1)}$ Dept. of Chemical System Engineering, Graduate School of Engineering, The University of Tokyo, \\ 7-3-1 Hongo, Bunkyo-ku, Tokyo 113-8656, JAPAN \\ ${ }^{\dagger 2}$ Center for Energy \& Environmental Science, Shinshu University, 4-17-1 Wakasato, Nagano 380-8553, JAPAN
}

(Received December 26, 2018)

\begin{abstract}
Hydrogen production by photocatalytic water splitting under sunlight is one of the most promising approaches to addressing present day energy and environmental issues. For this reason, the research and development of systems for this purpose has recently accelerated on a worldwide basis. This review summarizes developments in the field of photocatalytic water splitting under visible light, especially systems using particulate photocatalysts. Focusing on visible-light-responsive photocatalyst materials, both one-step and two-step excitation systems are examined, as well as recently reported photocatalyst sheet systems in which particulate photocatalysts are fixed on a conductive plate. Some topics related to reactor designs incorporating UV-responsive model photocatalysts are also addressed. Finally, this review describes a demonstration of water splitting under actual sunlight using a $1 \mathrm{~m} \times 1 \mathrm{~m}$ prototype reactor that exhibits a solar to hydrogen conversion efficiency of approximately $0.4 \%$.
\end{abstract}

\section{Keywords}

Photocatalyst, Water splitting, Solar hydrogen production, Solar water splitting reactor

\section{Introduction}

The energy imparted to the Earth's surface by solar irradiance is approximately $3.0 \times 10^{24} \mathrm{~J} /$ year. This irradiation would be sufficient to meet the current overall energy requirements of human activity if only $0.015 \%$ could be employed. However, sunlight provides a low energy density per unit area and fluctuates over time. In addition, the regions where solar energy is harvested are typically localized and far from the areas where energy is actually consumed. Therefore, in order to utilize solar energy efficiently, technologies to convert this energy to storable and transportable forms on a large scale are required.

Hydrogen can be used as a storable and transportable fuel that releases energy by combustion or by conversion to electricity in fuel cells. Moreover, the combustion of hydrogen generates only water and thus has minimal environmental impact. Therefore, it has been suggested that present day energy and environmental problems could be largely mitigated if systems for the large scale production of hydrogen from water under sunlight can be developed.

\footnotetext{
DOI: doi.org/10.1627/jpi.62.120

* To whom correspondence should be addressed.

* E-mail: domen@ chemsys.t.u-tokyo.ac.jp
}

\section{Photocatalytic Water Splitting Systems under UV Light}

Pioneering work by Honda and Fujishima in 1972 1 ) demonstrated that water could be split into hydrogen and oxygen in response to light irradiation when using $\mathrm{TiO}_{2}$ as a catalyst. Since then, photocatalytic and/or photoelectrochemical water splitting has attracted significant attention as a means of producing hydrogen. One of the present authors, together with several colleagues, published the first report in 1980 of steady water splitting under UV light by a $\mathrm{SrTiO}_{3}$ particulate photocatalyst modified with $\mathrm{Ni} / \mathrm{NiO}$ having a core/shell structure, as well as an analysis of the associated mechanism ${ }^{2), 3)}$. This represented the first-ever demonstration of a photocatalytic water splitting system based on a particulate photocatalyst. This work also provided the first evidence that the active structure in such materials comprises particulate semiconductors that absorb light along with hydrogen evolution sites attached to the surfaces of photocatalyst particles (so-called cocatalysts) at which protons are reduced to hydrogen by photoexcited electrons. This basic active structure remains common to almost all water splitting systems.

A wide variety of photocatalytic systems capable of splitting water has since been reported. However, most such systems employ oxide photocatalysts that absorb only UV light (that is, wavelengths shorter than 
$400 \mathrm{~nm})^{4}$. $\quad$ Because UV light is only a minor component of solar radiation, the efficient utilization of solar energy requires the development of water splitting systems driven by visible light.

\section{Water Splitting Systems under Visible Light}

\section{1. One-step Excitation Systems Using a Single Photocatalyst}

In the case of one-step excitation water splitting systems using one specific photocatalyst, thermodynamic considerations require that two conditions are satisfied. Specifically, the conduction band minimum of the photocatalyst must be located at a more negative potential than the reduction potential of water $(0 \mathrm{~V} v s$. a normal hydrogen electrode, $\mathrm{NHE}$, at $\mathrm{pH}=0$ ), and the valence band maximum of the photocatalyst must be located at a more positive potential than the oxidation potential of water $(+1.23 \mathrm{~V} v s$. NHE at $\mathrm{pH}=0)$.

In general, because the valence bands of oxides are primarily composed by $\mathrm{O} 2 \mathrm{p}$ orbitals, the associated valence band maximums are situated at positive potentials $(>+3 \mathrm{~V} v$ s. $\mathrm{NHE}$ at $\mathrm{pH}=0)$ higher than that for water oxidation. As a result, photogenerated holes have significant oxidation potential and thus preferentially drive the water oxidation reaction. However, in order to also reduce water, a band gap greater than $3 \mathrm{eV}$ is required, meaning that visible light cannot be used. The authors' group has surveyed visible-light-driven materials and determined that (oxy)nitrides and oxysulfides, whose valence bands consist partly of $\mathrm{N} 2 \mathrm{p}$ or S $3 p$ orbitals, show promise as water splitting photocatalysts operating under visible light.

In 2006, the first report of a one-step excitation water splitting system under visible light was reported, based on a particulate photocatalyst made of a solid solution of $\mathrm{GaN}$ and $\mathrm{ZnO}(\mathrm{GaN}: \mathrm{ZnO})^{5) \sim 8)}$. Both $\mathrm{GaN}$ and $\mathrm{ZnO}$ are wide gap materials that absorb only UV light. However, solid solutions of $\mathrm{GaN}$ and $\mathrm{ZnO}$ can absorb visible light up to approximately $500 \mathrm{~nm}$. This $\mathrm{GaN}: \mathrm{ZnO}$ photocatalyst exhibited high activity during the water splitting reaction when modified with $\mathrm{Rh} /$ $\mathrm{CrO}_{x}$ having a core/shell structure, or the mixed oxide $\mathrm{Rh}_{2-y} \mathrm{Cr}_{y} \mathrm{O}_{3}$, as hydrogen evolution cocatalysts. As shown in Fig. 1, steady hydrogen and oxygen evolution at the expected stoichiometric ratio of $2: 1$ was confirmed under visible light $(>400 \mathrm{~nm})$. The maximum quantum efficiency reported for this system was $5.1 \%$ at $410 \mathrm{~nm}$, corresponding to a solar to hydrogen conversion efficiency $(\mathrm{STH})$ of approximately $0.2 \%$. The durability of this system was also evaluated and water splitting activity under visible light was maintained for at least three months ${ }^{9}$.

Although the $\mathrm{GaN}: \mathrm{ZnO}$ described above was the first reported instance of overall water splitting under visible light, the utilization of light was limited to wavelengths

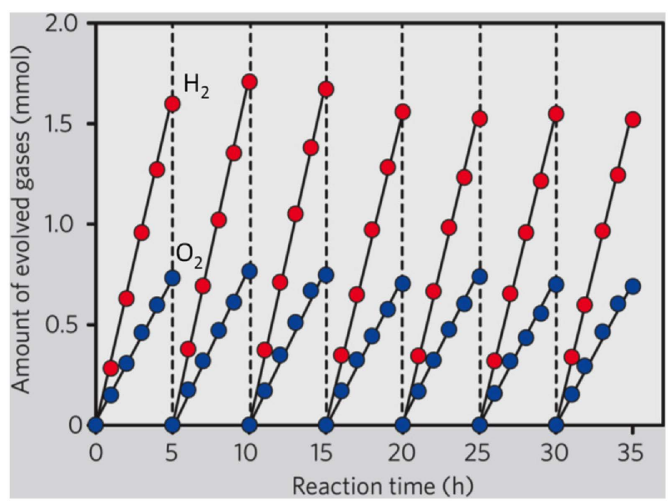

Fig. 1 The Time Course of Overall Water Splitting over GaN:ZnO under Visible Light.

[Reprinted with permission from ref. 6).]

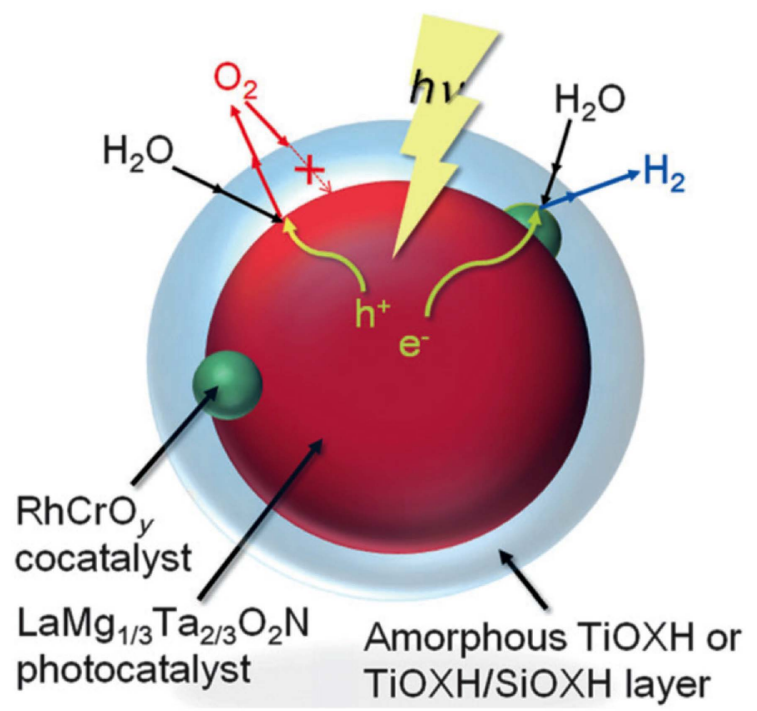

Fig. 2 A Schematic Diagram of Water Splitting over Surface-coated $\mathrm{LaMg}_{1 / 3} \mathrm{Ta}_{2 / 3} \mathrm{O}_{2} \mathrm{~N}$

[Reprinted with permission from ref. 10).]

below $500 \mathrm{~nm}$. Thus, a maximum STH of only approximately $8 \%$ would be the maximum obtainable by using all photons up to $500 \mathrm{~nm}$ for hydrogen production in the case of a quantum efficiency of unity. Therefore, efficient utilization of solar energy will require water splitting systems that can use light of longer wavelengths.

In 2015 a one-step excitation water splitting system capable of employing wavelengths up to $600 \mathrm{~nm}$ was reported $^{10)}$. This system used a particulate photocatalyst made of $\mathrm{LaMg}_{1 / 3} \mathrm{Ta}_{2 / 3} \mathrm{O}_{2} \mathrm{~N}$, which is considered to be a solid solution of $\mathrm{LaMg}_{2 / 3} \mathrm{Ta}_{1 / 3} \mathrm{O}_{3}$ and $\mathrm{LaTaON}_{2}$. As shown schematically in Fig. 2, appropriate surface modification by amorphous $\mathrm{TiO}_{x}$ suppressed selfoxidation of the photocatalyst and backward reactions, resulting in overall water splitting under visible light. This system was found to utilize light up to $600 \mathrm{~nm}$ 
based on examining the wavelength dependence of the water splitting activity. The maximum quantum efficiency reported for this system was $0.03 \%$ at $440 \mathrm{~nm}$. Thus, improvement of the water splitting activity is the most important goal associated with such systems.

\section{2. Two-step Excitation Systems Using Two Photocatalyst}

In the case of the one-step excitation water splitting systems described above, the thermodynamic requirement regarding the band position of the photocatalyst is challenging, since both the oxidation and reduction reactions of water must proceed over a single photocatalyst. In contrast, a two-step excitation system incorporates two photocatalysts: one for water oxidation and the other for water reduction. Thus, the band position requirements are relaxed. The only requirement for the water reduction photocatalyst is the location of the conduction band minimum while the position of the valence band maximum is the sole requirement for the water oxidation catalyst. Thus, various photocatalyst materials can be applied to two-step excitation systems, although the photon utilization efficiency is typically inferior to that of one-step excitation systems because both photocatalysts must be excited. In addition, the overall system requires redox couples to consume extra photo-excited carriers, such as holes generated in the water reduction photocatalyst.

The first two-step excitation water splitting system under visible light was reported in 2001 ${ }^{11)}$. In this system, $\mathrm{Cr}$ and Ta-doped $\mathrm{SrTiO}_{3}$ was used as the water reduction photocatalyst, while $\mathrm{WO}_{3}$ was employed for water oxidation, together with the $\mathrm{I}^{-} / \mathrm{IO}_{3}{ }^{-}$redox couple for charge transfer between the photocatalysts. This system utilized light up to $440 \mathrm{~nm}$ with a quantum efficiency of approximately $0.1 \%$ at $420.7 \mathrm{~nm}$.

Since that time, various two-step excitation systems under visible light have been developed. TaON, $\mathrm{CaTaO}_{2} \mathrm{~N}, \mathrm{BaTaO}_{2} \mathrm{~N}$, Rh-doped $\mathrm{SrTiO}_{3}, \mathrm{Sm}_{2} \mathrm{Ti}_{2} \mathrm{~S}_{2} \mathrm{O}_{5}$, $\mathrm{La}_{5} \mathrm{Ti}_{2} \mathrm{CuS}_{5} \mathrm{O}_{7}$ and other materials have been applied as water reduction photocatalysts, together with $\mathrm{TaON}$, $\mathrm{WO}_{3}, \mathrm{BiVO}_{4}$ or $\mathrm{Ta}_{3} \mathrm{~N}_{5}$ for water oxidation ${ }^{4), 12)}$ and $\mathrm{I}^{-} /$ $\mathrm{IO}_{3}{ }^{-}, \mathrm{I}^{-} / \mathrm{I}_{3}{ }^{-}$or $\mathrm{Fe}^{3+} / \mathrm{Fe}^{2+}$ as redox couples. Two-step excitation systems without redox couples have also been designed ${ }^{13)}$. In such systems, charge transfer between the two photocatalysts is believed to proceed during collisions between the particles of these materials. The authors' group has reported a two-step excitation system containing $\mathrm{TaON}$ as the water reduction photocatalyst and $\mathrm{WO}_{3}$ for oxidation. This combination of materials generated a quantum efficiency of approximately $6.3 \%$ at $420.5 \mathrm{~nm}^{14)}$, corresponding to an STH on the order of $0.1 \%$.

\section{3. New Two-step Excitation Systems Based on Photocatalyst Sheets}

Photocatalytic water splitting systems using the particulate photocatalysts described above have typically

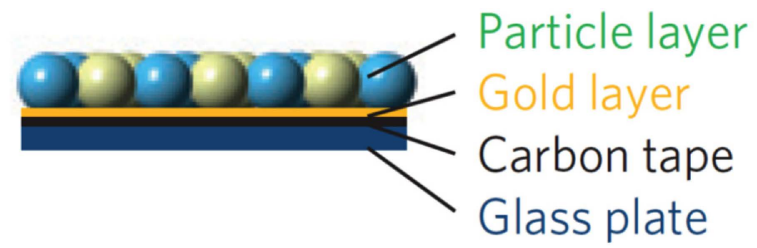

Fig. 3 A Schematic Diagram of a Photocatalyst Sheet [Reprinted with permission from ref. 15).]

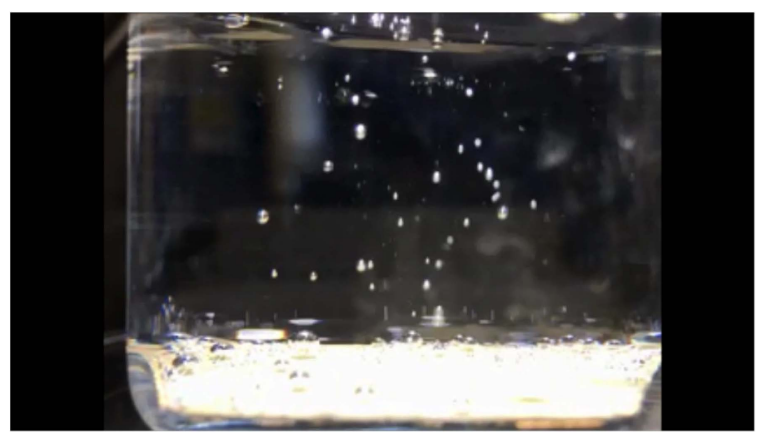

Fig. 4 A Photographic Image Acquired during Water Splitting over a Photocatalyst Sheet under Simulated Sunlight

[Reprinted with permission from ref. 15).]

been constructed and evaluated based on stirred powder suspensions in water. However, this is impractical because the stirring represents an additional energy input. In addition, a reactor design employing particulate photocatalysts fixed on solid plates would have several advantages, such as ready exchange of the catalytic materials.

In 2016, a two-step water splitting system based on photocatalyst sheets comprising two photocatalysts fixed on glass plates was reported ${ }^{15}$. $\quad$ Mo-doped $\mathrm{BiVO}_{4}$ and $\mathrm{La}, \mathrm{Rh}$-doped $\mathrm{SrTiO}_{3}$ were used as the water oxidation and reduction photocatalysts, respectively. As shown schematically in Fig. 3, both photocatalysts were fixed on the glass plate and connected via a thin $\mathrm{Au}$ layer. Irradiation by simulated sunlight (air mass $1.5 \mathrm{G}$ ) clearly resulted in gas evolution from this system, as shown in Fig. 4, together with very high water splitting activity. The quantum efficiency from this process was over $30 \%$ at $419 \mathrm{~nm}$ and the STH was greater than $1 \%$. Interestingly, when the same photocatalysts are employed in suspension, the resulting water splitting activity is not as high ${ }^{16)}$. The superior performance of the plate units is attributed to the electrical connection between both photocatalysts via the $\mathrm{Au}$ layer, such that carrier transport between the photocatalysts is improved, resulting in drastic enhancement of the activity. In addition, a similar level of water splitting activity is observed when a carbon layer is substituted for the Au layer ${ }^{17)}$.

It should be noted that these photocatalyst sheets exhibit high water splitting activity in neutral pure water 


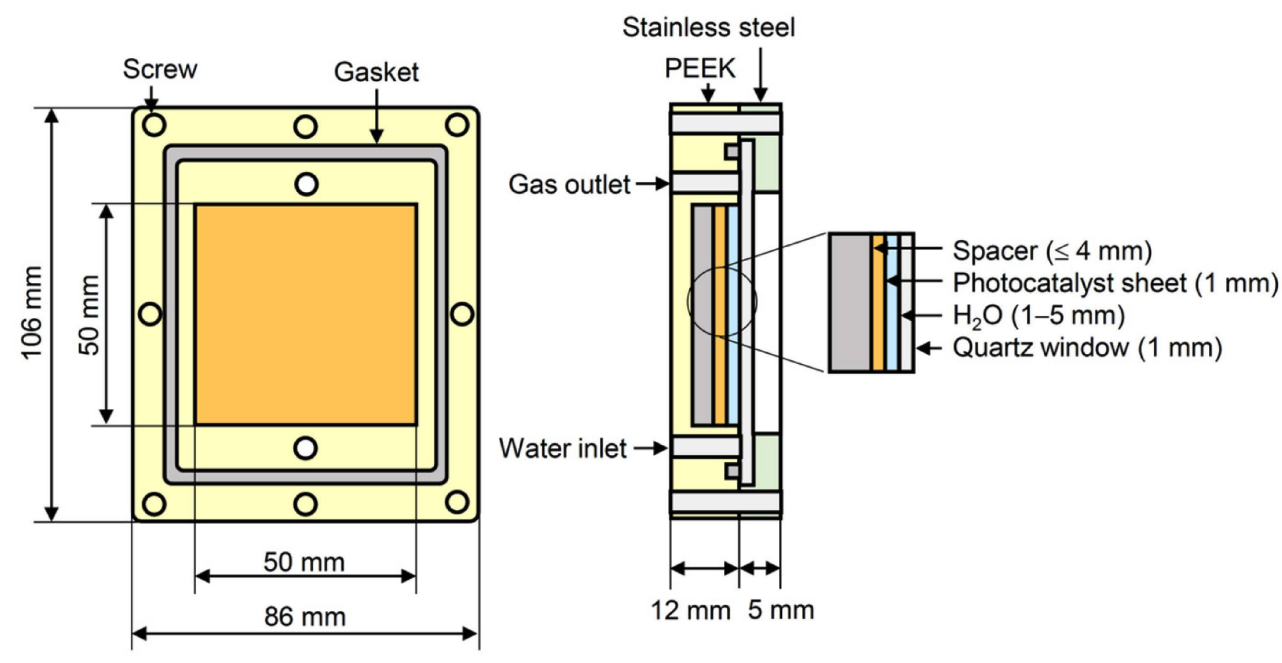

Fig. 5 A Schematic Illustration of a $5 \mathrm{~cm} \times 5 \mathrm{~cm}$ Water Splitting Reactor

[Reprinted with permission from ref. 18).]

(i.e., at $\mathrm{pH}=7$ ). In the case of two-step excitation systems in conventional suspension form, the water splitting activity strongly depends on various solution parameters, such as $\mathrm{pH}$. In contrast, the water splitting activity of the sheets shows very little effect of $\mathrm{pH}$. This ability to maintain a high level of activity in pure water would be highly beneficial in practical applications.

Photocatalyst sheets can also be prepared using a screen printing method, meaning that this system has the potential to be extended to a much larger scale. This is also advantageous from an economic standpoint, because the production of the sheets can be performed without expensive vacuum processes.

\section{Water Splitting Reactors}

As noted, this review focuses primarily on the development of suitable photocatalyst materials. However, the practical application of water splitting systems has many other associated challenges related to reactors and operations. As an example, considering a $1 \mathrm{~m} \times 1 \mathrm{~m}$ photocatalytic water splitting reactor, the weight of the aqueous reactant media would be $10 \mathrm{~kg}$ assuming a $1 \mathrm{~cm}$ deep water layer. In addition, the products are a mixture of hydrogen and oxygen, and so a means of separating these gases, such as membranes, is required. Because this mixture of gases is explosive, there are also safety concerns.

The authors' group has previously investigated reactor designs based on Al-doped $\mathrm{SrTiO}_{3}(\mathrm{Al}: \mathrm{STO})^{18)}$. Although Al:STO is only responsive to UV light, it exhibits high water splitting activity under UV irradiation, with a quantum efficiency of over $50 \%$ at $365 \mathrm{~nm}$, and so was used as a model photocatalyst for reactor designs. A $5 \mathrm{~cm} \times 5 \mathrm{~cm}$ sheet was prepared by drop cast-

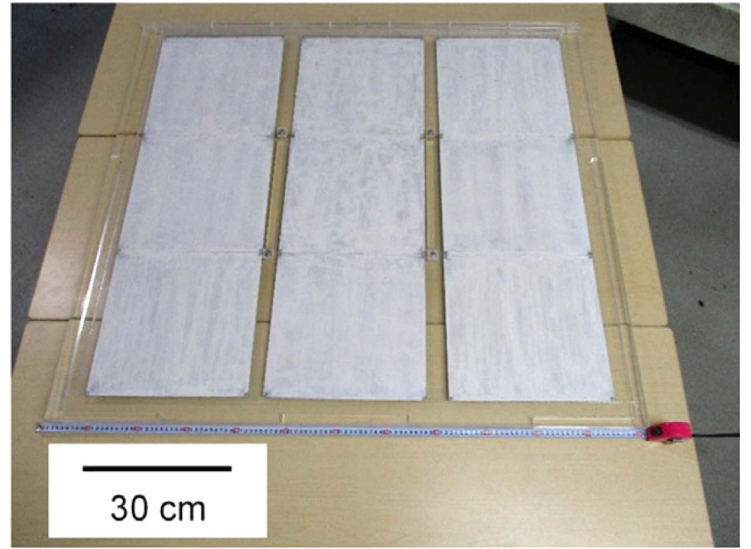

Fig. 6 A Photographic Image of a $1 \mathrm{~m} \times 1 \mathrm{~m}$ Water Splitting Panel [Reprinted with permission from ref. 18).]

ing $\mathrm{Al}$ :STO onto a glass plate and the photocatalytic activity was evaluated in the reactor apparatus shown in Fig. 5 while adjusting the distance between the quartz window and the sheet to ascertain the effects of the water layer thickness on activity. This prior work confirmed that a water layer as thin as $1 \mathrm{~mm}$ was sufficient to allow the water splitting reaction to proceed steadily. It was also evident that with gas evolution rate of $3.7 \mathrm{~mL} \mathrm{~cm}^{-2} \mathrm{~h}^{-1}$, which corresponds to an STH of $10 \%$, the evolved gas behaviour was affected by pre-treatment of the quartz window (to make it hydrophilic or hydrophobic). In the case of a hydrophilic window, small bubbles were readily released from the surface of the photocatalyst sheet, while a hydrophobic window caused the growth of large bubbles. Thus, employing a hydrophilic window is desirable so as to avoid the accumulation of an explosive gas mixture in the reactor.

Figure 6 shows a $1 \mathrm{~m} \times 1 \mathrm{~m}$ prototype reactor con- 
taining nine photocatalyst sheets, each $33 \mathrm{~cm} \times 33 \mathrm{~cm}$. This reactor was able to perform the water splitting reaction under actual sunlight and gas evolution corresponding to an STH of $0.4 \%$ was observed.

\section{Summary}

Recently, photocatalytic hydrogen production from water under sunlight has attracted significant attention as a type of artificial photosynthesis, and has been researched worldwide. Although improvement of the water splitting activity (i.e., the STH) is currently the most important aspect of particulate photocatalyst systems, both the visible light responsive photocatalyst materials themselves and surface modifications, including the development of cocatalysts, have been advanced. It should also be noted that, while this review focused on particulate photocatalyst systems, photoelectrochemical systems have been developed as well and have demonstrated high conversion efficiencies. However, these systems have challenges regarding scalability and economics. Both particulate photocatalyst and photoelectrochemical systems also have many areas where additional work is required, such as in reactor and/or total system design, and such work is ongoing. It is likely that, in the near future, photocatalytic water splitting systems that meet all the requirements for practical applications, including energy conversion efficiency, scalability, economical operation and safety, will be developed.

\section{Acknowledgment}

This work was financially supported by Grant-in Aid for Scientific Research (A) (no. 16H02417) from the Japan Society for the Promotion of Science (JSPS) and by the Artificial Photosynthesis Project of the New Energy and Industrial Technology Development Organization (NEDO).

\section{References}

1) Fujishima, A., Honda, K., Nature, 238, 37 (1972).
2) Domen, K., Naito, S., Soma, M., Onishi, T., Tamaru, K., J. Chem. Soc., Chem. Commun., 12, 543 (1980).

3) Domen, K., Kudo, A., Onishi, T., Kosugi, N., Kuroda, H., J. Phys. Chem., 90, 292 (1986).

4) Kudo, A., Miseki, Y., Chem. Soc. Rev., 38, 253 (2009).

5) Maeda, K., Takata, T., Hara, M., Saito, N., Inoue, Y., Kobayashi, H., Domen, K., J. Am. Chem. Soc., 127, 8286 (2005).

6) Maeda, K., Teramura, K., Lu, D., Takata, T., Saito, N., Inoue, Y., Domen, K., Nature, 440, 295 (2006).

7) Maeda, K., Teramura, K., Lu, D., Saito, N., Inoue, Y., Domen, K., Angew. Chem. Int. Ed., 45, 7806 (2006).

8) Maeda, K., Teramura, K., Domen, K., J. Catal., 254, 198 (2008).

9) Ohno, T., Bai, L., Hisatomi, T., Maeda, K., Domen, K., J. Am. Chem. Soc., 134, 8254 (2012).

10) Pan, C., Takata, T., Nakabayashi, M., Matsumoto, T., Shibata, N., Ikuhara, Y., Domen, K., Angew. Chem. Int. Ed., 54, 2955 (2015).

11) Sayama, K., Mukasa, K., Abe, R., Abe, Y., Arakawa, H., Chem. Commun., 2416 (2001).

12) Sun, S., Hisatomi, T., Wang, Q., Chen, S., Ma, G., Liu, J., Nandy, S., Minegishi, T., Katayama, M., Domen, K., ACS Catal., 8, 1690 (2018).

13) Sasaki, Y., Nemoto, H., Saito, K., Kudo, A., J. Phys. Chem. C, 113, 17536 (2009).

14) Maeda, K., Higashi, M., Lu, D., Abe, R., Domen, K., J. Am. Chem. Soc., 132, 5858 (2010).

15) Wang, Q., Hisatomi, T., Jia, Q., Tokudome, H., Zhong, M., Wang, C., Pan, Z., Takata, T., Nakabayashi, M., Shibata, N., Li, Y., Sharp, I. D., Kudo, A., Yamada, T., Domen, K., Nature Mater, 15, 611 (2016).

16) Wang, Q., Li, Y., Hisatomi, T., Nakabayashi, M., Shibata, N., Kubota, J., Domen, K., J. Catal., 328, 308 (2015).

17) Wang, Q., Hisatomi, T., Suzuki, Y., Pan, Z., Seo, J., Katayama, M., Minegishi, T., Nishiyama, H., Takata, T., Seki, K., Kudo, A., Yamada, T., Domen, K., J. Am. Chem. Soc., 139, 1675 (2017).

18) Goto, Y., Hisatomi, T., Wang, Q., Higashi, T., Ishikiriyama, K., Maeda, T., Sakata, Y., Okunaka, S., Tokudome, H., Katayama, M., Akiyama, S., Nishiyama, H., Inoue, Y., Takewaki, T., Setoyama, T., Minegishi, T., Takata, T., Yamada, T., Domen, K., Joule, 2, 509 (2018). 
要旨

\section{太陽光照射下で水から水素を製造する高効率光触媒系の開発}

片山 正士 ${ }^{\dagger 1)}$, 堂免 一成 ${ }^{\dagger 1, \dagger 2)}$

†1) 東京大学大学院工学系研究科化学システム工学専攻, 113-8656 東京都文京区本郷7-3-1

†2) 信州大学環境エネルギー材料科学研究所, 380-8553 長野市若里4-17-1

太陽光照射下での光触媒を用いた水の分解による水素製造は エネルギー環境問題を解決する手法として有望な手段の一つで あり, 近年世界中で研究開発が加速している。本稿では可視光 照射下での光触媒を用いた水分解系の構築について, 特に粉末 光触媒を用いた系について概説する。一段階励起系および二段 階励起系に関して主として可視光応答型光触媒材料に着目して
述べた後, 近年開発された粉末光触媒を導電性基板に固定化し た光触媒シート系について述べる。また, 紫外光応答型光触媒 をモデル光触媒として用いた反応器設計についても言及する。 さらに, $1 \mathrm{~m}^{2}$ サイズの反応系を試作, 実太陽光照射下での水分 解反応を実施し, 太陽光水素エネルギー変換効率約 $0.4 \%$ に相 当する気体生成が観察された。 